\title{
KOPOLIMER HIBRID TMSPMA:TEMS SEBAGAI MATRIKS IONIK PADA SEL SURYA TERSENSITISASI DYE
}

\author{
Annisa Aprilia ${ }^{1, \text { a) }}$, Waode Sukmawati Arsyad ${ }^{2}$, R.N. Lamuda ${ }^{1}$, Fitrilawati ${ }^{1}$, \\ Norman Syakir ${ }^{1}$, Rahmat Hidayat ${ }^{3}$ \\ ${ }^{I}$ Departemen Fisika, FMIPA, Universitas Padjadjaran, Jl. Raya Bandung-Sumedang KM 21, Jatinangor \\ 45363, Jawa Barat \\ ${ }^{2}$ Departemen Fisika FMIPA Universitas Halu Oleo, Anduonohu 93232, Kendari, Sulawesi Tenggara \\ ${ }^{3}$ Departemen Fisika, FMIPA, Institut Teknologi Bandung, Jl. Ganesa 10 Bandung 40132, Jawa Barat
}

Email: a) a.aprilia@phys.unpad.ac.id

\begin{abstract}
Abstrak
Beberapa tipe elektrolit pada divais DSSC (dye sensitized solar cell) yang telah banyak diteliti dan digunakan yaitu elektrolit padat, semi padat dan cair. Pada divais DSSC konvensional, penggunaan elektrolit cair umumnya menghasilkan efisiensi yang relatif lebih tinggi berkaitan dengan tingginya mobilitas muatan. Permasalahan dalam penggunaan elektrolit cair yaitu kemungkinan adanya kebocoran divais. Salah satu upaya dalam mengatasi hal tersebut adalah dengan menggunakan elektrolit padat atau semi padat. Penelitian kali ini mencoba menggunakan elektrolit semi-padat (EGP-elektrolit gel polimer) berbasis polyetylene glikol (PEG) yang dimodifikasi dengan penambahan kopolimer hibrid TMSPMA:TEMS (3:1) sebagai matriks bagi larutan ionik (mosalyte). Untuk mengetahui pengaruh matriks kopolimer hibrid pada EGP, dilakukan karakterisasi EIS (electrochemical impedance spectroscopy) pada bagian elektrolit gel, yang kemudian dilanjutkan dengan pembuatan divais DSSC berstruktur FTO/ $\mathrm{TiO}_{2}$ / Ru-dye/ EGP / Pt / FTO. Karakteristik sel surya terbaik yang elektrolit gelnya mengandung kopolimer TMSPMA:TEMS memiliki nilai rapat arus $\left(\mathrm{J}_{\mathrm{sc}}\right)$ sebesar $3,7 \mathrm{~mA} / \mathrm{cm}^{2}$, tegangan terbuka $\left(\mathrm{V}_{\text {oc }}\right)$ 0,56 Volt, dan efisiensi 3,65\% dengan daya masukan $\left(\mathrm{P}_{\text {in }}\right)$ yang digunakan sebesar 36 $\mathrm{mW} / \mathrm{cm}^{2}$.
\end{abstract}

Kata-kata kunci: Kopolimer hibrid, larutan ionik, sel surya DSSC, elektrolit gel, spektroskopi impedansi.

\begin{abstract}
Three types of electrolyte on dye sensitized solar cell (DSSC) are liquid, solid state, and quasi-solid phase electrolytes. Among these electrolytes quasi-solid phase was expected could be handle some of disadvantages both of liquid and solid state phase on device peformance related to leakage (for liquid phase) and low ionic diffusion (for solid state phase). In conventional DSSC using liquid electrolyte a better efficiency can achieved by high ionic mobility but it is easy to leak leading to lower durabilty performance. In order to enhance durability, many researcher were change the liquid phase by solid state or quasi solid as its electrolyte. This research also try to study the effect of quasi solid electrolyte based on polyetylene glicol modified by hybrid copolymer precursor TMSPMA: TEMS (3:1) as a matrix for ionic liquid. This kind electrolyte is called as polymer gel electrolyte (PGE). Impedance characteristics for PGE was carried out to study electrical characteristics and subsequently applied on solar cell device with structure FTO/ $\mathrm{TiO}_{2}$ / Ru-dye/ PGE / Pt / FTO. Solar cell device with PGE that consist both of polyetylen glicol and copolymer TMSPMA:TEMS have an efficiency of $3.65 \%$ under light source $\mathrm{P}_{\text {in }}=$
\end{abstract}


$36 \mathrm{~mW} / \mathrm{cm}^{2}$ irradiation with short-circuit current density of $3.7 \mathrm{~mA} / \mathrm{cm}^{2}$ and open circuit voltage of 0.56 volt was obtained.

Keywords: hybrid copolymer, ionic liquid, polymer gel electrolyte, impedance spectroscopy.

\section{PENDAHULUAN}

Teknologi sel surya tersensitasi dye (dye sensitized solar cell) atau yang dikenal dengan istilah DSSC memperlihatkan peningkatan kinerja yang signifikan, berkaitan dengan ditemukannya berbagai material baru dan inovasi struktur pada material penyusunnya. Peningkatan efisiensi pada tipe DSSC menggunakan elektrolit cair telah mencapai 12,3\% pada tahun 2011 [1]. Salah satu upaya untuk meningkatkan kinerja sel surya DSSC adalah dengan mengoptimasi bagian elektrolit. Terdapat 3 tipe DSSC berdasarkan jenis elektrolitnya yaitu DSSC cair, semi padat (quasi-solid) dan padat. Pada elektrolit padat (polimer atau semikonduktor tipe-p) telah dianggap kurang maksimal dalam menghantar muatan, disebabkan oleh rendahnya difusi ionik dalam matriks polimer, sedangkan elektrolit cair dinyatakan mudah mengalami kebocoran [2]. Penggunaan elektrolit semi-padat (fasa gel) diharapkan dapat mengatasi kekurangan kedua elektrolit tersebut (cair dan padat), serta diasumsikan dapat menghasilkan kinerja sel yang lebih baik [2,3]. Elektrolit pada sistem DSSC berperan dalam mentrasportasikan muatan yang dihasilkan pada bagian dye. Penggunaan elektrolit gel diupayakan dapat meningkatkan durabilitas/daya tahan divais bila dibandingkan dengan divais DSSC konvensional ber-elektrolit (cair) serta menawarkan kemudahan dalam fabrikasi dibandingkan dengan DSSC berbahan padat.

Beberapa studi mengenai penggunaan matriks berbasis siloksan (polimer hibrid) sebagai medium bagi larutan ionik (cairan elektrolit) sehingga membentuk polimer gel elektrolit (PEG), telah banyak diteliti dan dikembangkan. Salah satunya adalah yang berbasis TMSPMA (3-(Trimethoxysilyl) propyl methacrylate) yang telah diketahui bahwa menunjukkan kinerja divais yang sebanding dengan menggunakan elektrolit cair [4]. Selain itu peneliti lain telah memvariasikan bagian elektrolit gel dengan penambahan molekul dye, sehingga dapat meningkatkan efisiensi divais [5]. Penelitian ini akan membahas penggunaan jenis elektrolit gel berbasis polyetilen glikol yang dimodifikasi dengan kopolimer hibrid TMSPMA: TEMS (triethoxymethylsilane) sebagai matriks bagi cairan ionik. Penggunaan matriks kopolimer hibrid (gabungan dari dua polimer) tersebut pada politelen glikol bertujuan untuk meningkatkan viskositas, sedangkan polietilen glikol merupakan salah satu jenis polimer yang bersifat polar sehingga dapat meningkatkan mobilitas pembawa muatan [6].

\section{METODE PENELITIAN}

Proses persiapan elektrolit gel, dimulai dari proses sintesis prekursor kopolimer hibrid menggunakan monomer 3-(Trimethoxysilyl) propyl methacrylate) (TMSPMA) dan monomer Triethoxymethylsilane (TEMS) (3:1) mengikuti prosedur yang telah dilakukan sebelumnya [7,8]. Pembuatan elektrolit gel yaitu dengan menambahkan kopolimer hibrid poli (TMSPMA-TEMS) pada polietilen glikol dengan pelarut yang digunakan adalah propilen karbonat (PC), kemudian dilanjutkan pada pembuatan elektrolit gel menggunakan medium komposit dan cairan ionik mosalyte (mos). Sedangkan proses fabrikasi divais berstruktur FTO/ $\mathrm{TiO}_{2}$ / Ru-dye/ EGP / Pt / FTO, dimulai dengan proses pelapisan pasta $\mathrm{TiO}_{2} \mathrm{~T} / \mathrm{SP}$ (solaronix SA) menggunakan teknik screen printing sebanyak 3 kali pelapisan pada substrat FTO (fluorine tin oxide; $13 \Omega / \mathrm{cm}^{2}$ ). Dalam upaya meningkatkan serapan dye, maka dilakukan pula pelapisan microchannel $\mathrm{TiO}_{2}-\mathrm{MC}$ (solaronix SA) setelah pasta $\mathrm{TiO}_{2}$ mengalami pemanasan hingga $500{ }^{\circ} \mathrm{C}$ selama 30 menit untuk proses kristalisasi. Ruthenium dye N719 (solaronix) digunakan sebagai dye yang dilarutkan etanol dengan menambahkan chenodeoxolicacid dengan perbandingan 1:10. Perendaman lapisan fotoanoda di dalam larutan dye dilakukan selama semalaman. Untuk memaksimalkan serapan dye pada pori-pori titania, proses perendaman dimulai pada saat fotoanoda bertemperatur $60{ }^{\circ} \mathrm{C}$. Sampel yang telah mengalami perendaman kemudian dibilas dengan acetonitril untuk menghilangkan partikel dye yang tidak terserap. Selanjutnya adalah proses perakitan sel surya dengan menggunakan suryln (solaronix SA) 
berketebalan $25 \mu \mathrm{m}$ yang kemudian ditumpuk dengan FTO yang telah terlapisi Pt (platina) sebagai counter electrode yang memiliki lubang sebagai akses bagi elektrolit.

Elektrolit gel polimer (EGP) yang terdiri dari beberapa variasi komposisi kemudian diinjeksikan menggunakan vakum syringe ke dalam sel, diakhiri dengan menutup lubang akses menggunakan tape (selotip) transparan. Beberapa pengukuran meliputi spektroskopi impedansi khusus untuk bagian elektrolit gel (PEG) dilakukan untuk mengetahui sifat listrik dari elektrolit gel tersebut. Sedangkan untuk mengetahui pengaruh penambahan kopolimer hibrid dalam PEG terhadap kinerja divais, dilakukan pengukuran karakteristik arus-tegangan (kurva I-V) menggunakan sumber arustegangan Yokogawa GS200 dan multimeter digital Yokogawa 7555 beserta sumber lampu halogen Philips dengan intensitas daya sebesar $36 \mathrm{~mW} / \mathrm{cm}^{2}$.

\section{HASIL DAN PEMBAHASAN}

Untuk mengetahui pengaruh penggunaan berbagai jenis medium bagi cairan ionik mosalyte yang terdiri dari matriks berbasis polietilen glikol dan kopolimer hibrid TMSPMA:TEMS, pengukuran spektroskopi impedansi dilakukan hanya pada bagian elektrolit saja, dengan struktur konfigurasi seperti pada gambar 1(a).
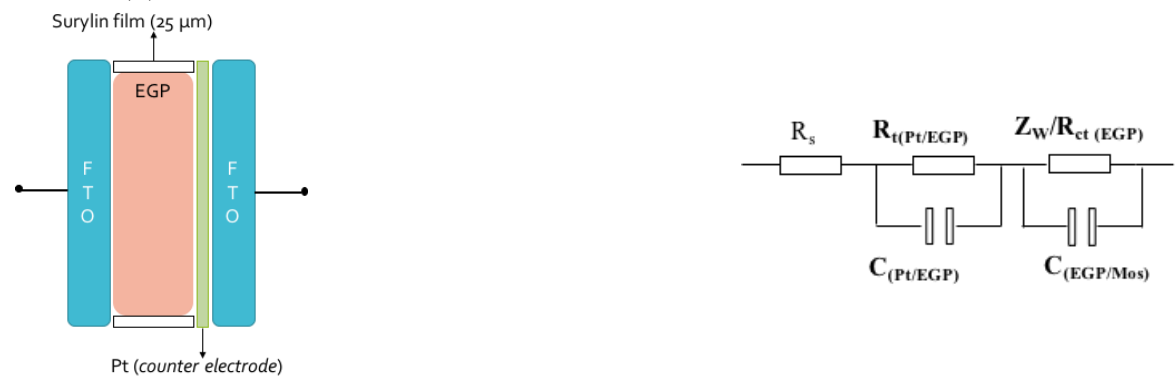

GAMBAR 1. (a) Struktur persambungan pada pengukuran EIS untuk bagian elektrolit gel polimer(EGP). (b) Rangkaian ekivalen untuk medium matriks ionik.

Beberapa parameter resistansi dan kapasitansi hasil dari pengukuran spektroskopi impedansi elektrolit gel polimer dengan variasi komposisi diperlihatkan pada tabel 1 dengan diagram ekivalen yang bersesuaian diperlihatkan pada gambar 1(b), sedangkan kurva Nyquist diperlihatkan pada gambar 2. $\mathrm{R}_{\mathrm{s}}$ merupakan hambatan seri elektroda $\mathrm{FTO} / \mathrm{Pt}, \mathrm{R}_{\mathrm{t}}$ adalah resistansi transfer muatan pada persambungan $\mathrm{Pt} / \mathrm{EGP}$ sedangkan $\mathrm{Z}_{\mathrm{w}}$ menyatakan impedansi difusi ionik muatan di dalam matriks EGP. Berdasarkan hasil pengukuran diketahui bahwa elektrolit gel polimer (EGP) yang terdiri dari kopolimer hibrid memiliki karakteristik difusi ionik yang ditunjukkan dengan keberadaan impedansi warburg $\left(Z_{w}\right)$ [9]. Sampel dengan matriks yang hanya terdiri dari kopolimer saja (tanpa propilen karbonat) memiliki nilai $Z_{\mathrm{w}}$ paling besar. Hal tersebut berkaitan dengan sifat transport massa (ionion) yang bergerak di dalam matriks kopolimer (A) lebih lambat dibandingkan ketika berada di dalam matriks kopolimer yang mengandung pelarut propilen karbonat (B dan C). Selain itu nilai kapasitansi medium elektrolit gel $\left(\mathrm{C}_{(\mathrm{EGP} / \mathrm{Mos})}\right)$ memperlihatkan nilai yang semakin membesar seiring dengan penambahan pelarut propilen karbonat (PC) ataupun polietilen glikol (PEG). Sedangkan untuk elektrolit sampel D (PEG:Mos) nilai kapasitansi bernilai paling kecil yang mengindikasikan bahwa ion lebih mudah bergerak didalam medium tersebut [2,3]. Nilai $\mathrm{R}_{\mathrm{s}}$ merupakan besar resistansi kontak ohmik antara medium EGP dengan elektroda dan memperlihatkan orde yang sebanding pada seluruh sampel. Sama halnya dengan nilai resistansi transfer muatan antara FTO dan EGP, walaupun sampel $\mathrm{C}$ memiliki nilai $\mathrm{R}_{\mathrm{t}}$ dengan orde lebih besar, hal ini dapat disebabkan oleh penggabungan kopolimer dan PEG, disatu sisi menurunkan proses difusi ionik elektrolit (tidak adanya impedansi Warburg) tetapi meningkatkan resistansi dibagian persambungan elektroda dan elektrolit $\left(\mathrm{R}_{\mathrm{t}(\mathrm{Pt} / \mathrm{EGP})}\right)$. 


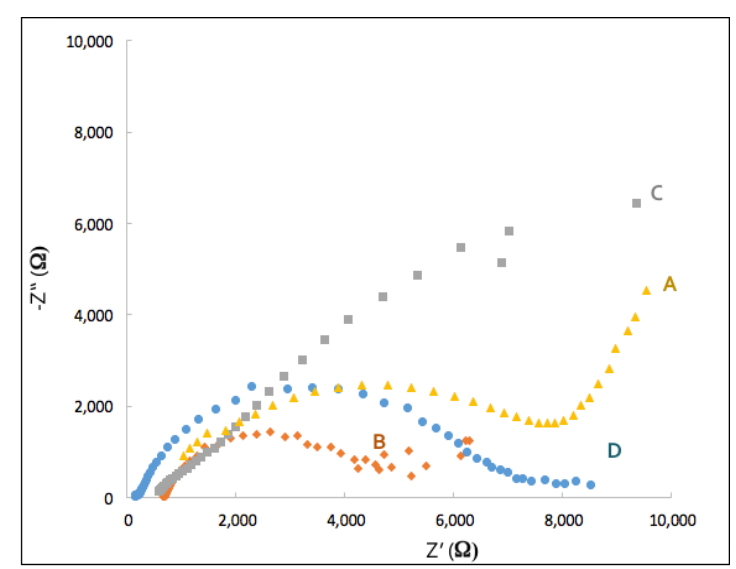

GAMBAR 2. Kurva Ny-Quist untuk elektrolit gel struktur (FTO/EGP/Pt/FTO). Sampel (A) kopolimer:Mos, (B)

Kopolimer:PC: Mos, (C) Kopolimer:PEG:Mos dan (D) PEG:Mos.

Untuk mengetahui peranan EGP sebagai elektrolit pada sistem DSSC, kemudian dilakukan pengukuran karakteristik arus-tegangan (I-V) pada divais dengan Struktur persambungan yang dibentuk adalah $\mathrm{FTO} / \mathrm{TiO}_{2} / \mathrm{Ru}$-dye/EGP/Pt/FTO. Hasil pengukuran dapat dilihat pada gambar 3 dengan masing-masing parameter hasil pengukuran diperlihatkan pada tabel 2.

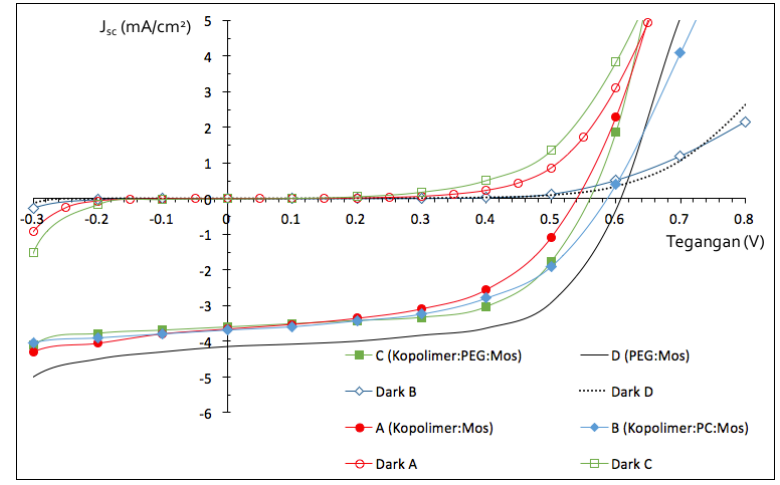

GAMBAR 3. Kurva karakteristik arus-tegangan pada divais sel surya dengan variasi elektrolit gel.

TABEL 1. Hasil pengukuran spektroskopi impedansi (hambatan dan kapasitansi) dari medium elektrolit gel

\begin{tabular}{|l|c|c|c|c|c|c|}
\hline \multicolumn{1}{|c|}{ Jenis elektrolit } & $\mathbf{R}_{\mathbf{s}}(\boldsymbol{\Omega})$ & $\mathbf{R}_{\mathbf{t}(\mathbf{P t} / \mathbf{E G P})(\boldsymbol{\Omega})}$ & $\mathbf{R}_{\mathbf{c t}(\mathbf{E G P})(\boldsymbol{\Omega})}$ & $\mathbf{Z}_{\mathbf{w}}(\boldsymbol{\Omega})$ & $\mathbf{C}_{(\mathbf{P t} / \mathbf{E G P})(\mu \mathrm{F})}$ & $\begin{array}{c}\mathbf{C}_{(\mathbf{E G P} / \mathbf{M o s})} \\
(\mu \mathrm{F})\end{array}$ \\
\hline Kopolimer:Mos (A) & 544 & $7 \mathrm{~K}$ & - & $1,8 \times 10^{5}$ & 0,58 & 1 \\
\hline Kopolimer:PC:Mos (B) & 680 & $3,7 \mathrm{~K}$ & - & $0,8 \mathrm{~K}$ & 6,4 & 5 \\
\hline Kopolimer:PEG:Mos (C) & 411 & $31 \mathrm{~K}$ & $5,7 \mathrm{~K}$ & - & 0,87 & 7,7 \\
\hline PEG:Mos (D) & 118 & $3,8 \mathrm{~K}$ & $4,4 \mathrm{~K}$ & - & 60 & 0,98 \\
\hline
\end{tabular}

Tabel 2. Parameter karakterisasi arus tegangan pada divais DSSC semi padat dengan daya input yang digunakan sebesar 36 $\mathrm{mW} / \mathrm{cm}^{2}$.

\begin{tabular}{|c|c|c|c|c|}
\hline $\begin{array}{c}\text { Sampel } \\
\text { Divais }\end{array}$ & $\begin{array}{c}\mathbf{V}_{\mathbf{o c}} \\
(\mathbf{V})\end{array}$ & $\begin{array}{c}\mathbf{J}_{\mathbf{s c}} \\
\left(\mathbf{m A} / \mathbf{c m}^{\mathbf{2}}\right)\end{array}$ & $\begin{array}{c}\mathbf{F F} \\
(\mathbf{\%})\end{array}$ & $\begin{array}{c}\mathbf{E f f} \\
(\boldsymbol{\%})\end{array}$ \\
\hline A & 0,53 & 3,65 & 53 & 2,86 \\
\hline B & 0,58 & 3,68 & 52 & 3,05 \\
\hline C & 0,56 & 3,7 & 60 & 3,65 \\
\hline D & 0,60 & 4,15 & 59 & 3,95 \\
\hline
\end{tabular}

Efisiensi sel tanpa menggunakan kombinasi kopolimer TMSPMA:TEMS (sampel D) memiliki nilai efisiensi yang paling besar bila dibandingkan dengan penggunaan elektrolit lainnya. Tentu saja hal ini berkaitan dengan polimer PEG (polietilen glikol) yang termasuk polimer bersifat polar [3] sehingga memiliki nilai konduktifitas ionik yang lebih tinggi dibandingkan ketiga sampel lainnya. Walaupun demikian penurunan efisiensi akibat penambahan kopolimer sebagai matriks ionik tidak 
terlalu besar, sehingga penggunaan kopolimer tersebut masih dapat dipotimalkan [4,6]. Berdasarkan pengamatan kekentalan secara visual, penambahan kopolimer meningkatkan viskositas secara signifikan dibandingkan dengan matriks PEG saja, sehingga diketahui secara jelas peranan kopolimer adalah meningkatkan viskositas walau disisi lain dapat menurunkan mobilitas ionik. Penurunan mobilitas ionik tersebut berdampak pula pada nilai rapat arus yang dihasilkan (tabel 2). Rapat arus $\left(\mathrm{J}_{\mathrm{sc}}\right)$ pada sel mengalami peningkatan seiring dengan penambahan PC dan PEG. Tetapi penambahan kopolimer pada sampel C menyebabkan peningkatan nilai fill factor (FF). Hal ini dapat dikaitkan dengan sifat kapasitansi $\left(\mathrm{C}_{(\mathrm{P} / \mathrm{EGP})}\right)$ di persambungan antara elektrolit dan elektroda pada sampel $\mathrm{C}$ lebih kecil dibandingkan dengan sampel D (tabel 1). Sifat kapasitansi yang lebih kecil mengindikasikan bahwa sifat kapasitif/menyimpan muatan berkurang sehingga dapat dikaitkan dengan transport muatan di daerah tersebut lebih tinggi dan memiliki kecenderungan mobilitas pembawa muatan yang seimbang antara dua elektroda dibandingkan sampel lainnya.

\section{KESIMPULAN}

Matriks polimer yang terdiri dari gabungan antara kopolimer hibrid TMPSMA:TEMS (3:1) dan polimer polietilen glikol (PEG) dapat berfungsi untuk menjebak larutan ionik mosalyte, sehingga berperan sebagai elektrolit gel (elektrolit gel polimer-EGP) pada sistem sel surya tersensitisasi dye (DSSC). Penambahan kopolimer hibrid tersebut berperan untuk meningkatkan kekentalan/viskositas EGP sehingga diharapkan tidak mudah mengalami kebocoran. Diketahui bahwa penambahan matriks kopolimer hibrid menyebabkan konduktifitas ionik menurun bila dibandingkan dengan hanya menggunakan polimer PEG sebagai matriks ionik. Penurunan konduktifitas ionik tersebut berkaitan dengan sifat non-polar dari gel kopolimer hibrid dan menyebabkan mobilitas ion terhambat sehingga sel mengalami penurunan efisiensi. Walau demikian gabungan antara PEG, kopolimer TMPSMA:TEMS dan pelarut propilen karbonat (PC) memperlihatkan peningkatan efisiensi sel dari 2,86\% menjadi 3,65\%, sehingga penambahan TMSPMA:TEMS dapat dioptimalkan penggunaannya agar kinerja divais dapat meningkat dan mampu menyaingi penggunaan elektrolit berfasa cair.

\section{UCAPAN TERIMAKASIH}

Penulis mengucapkan terimakasih kepada Direktorat Penelitian dan Pengabdian kepada Masyarakat (DRPM) Universitas Padjadjaran untuk mendanai penelitian Desentralisasi (Penelitian Unggulan Tinggi) Tahun Anggaran 2015 DIPA UNPAD berdasarkan surat penugasan nomor. 393/UN6.R/PL/2015 pada tanggal 16 Februari 2015.

\section{REFERENSI}

[1] Y.Meidan, W Xiaoru, W. Mengye, I. James, Z. Nan, L. Ahangjian and L. Zhiqun, Recent andvances in dye-sensitized solar cells: from photoanodes, sensitizers, and electrolytes to counter electrode, Materials Today, Vol. 18, No. 3, April 2015

[2] E. Aram, M. Ehsani, and H.A. Khonakdar, Improvement of ionic conductivity and performance of quasi-solid-state dye sensitized solar cell using PEO/PMMA gel electrolyte, Thermochimica Acta 615 (2015), 61-67.

[3] S.S. Alexander, M. Rebeca and M. David, Recent advances in innovative polymer electrolyte based on poly(ionic) liquid, Electrochimica Acta 175 (2015) 18-34.

[4] W. S. Arsyad, Herman, Fitrilawati, and R. Hidayat, Photovoltaic and impedance characteristics of quasi solid-state dye-sensitized solar cell using polymer gel electrolyte, Advanced Materials Research (AMR) Vol. 1112 (2015), pp. 256-261.

[5] H. Nansra, J. Yongseok and P. Hyeok, Dye molecule in electrolyte: new apporoach for suppression of dye-desorption in dye-sensitized solar cells, Scientific Report, 3:1712 (2013). 
[6] G. Anantharaj, J. Joseph, M. Selvaraj, and S. Jeyakumar, Fabrication of stable Sye sensitized Solar Cell with Gel Electrolytes Using Poly(etylene oxide)-Poly(ethylene glicol), Electrochimica Acta 175 (2015) 1403-1409.

[7] Fitrilawati, N. Syakir, A. P. Mastiti, U. Yuliani, dan A. Aprilia, Pemanfaatan polimer hibrid TMSPMA dan phosphor organik sebagai bahan luminesensi untuk solid state lighting planar, Jurnal Kimia dan Kemasan, Vol. 37 No. 1 April 2015, ISSN 2088-026X

[8] A. Aprilia, N. Syakir, Hendro, dan Fitrilawati, Deposisi lapisan tipis polimer hibrid TMSPMA:DCM dengan teknik spray-air brush sebagai bahan luminesensi pada LWC-SSL planar beserta karakteristik optiknya, Prosiding Seminar Nasional Fisika (2015), SNF2015VIII-9.

[9] J. R. Macdonald and W. B. Johnson, Impedance Spectroscopy Theory, Experiment, and Applications. 2nd ed. New Jersey (2005), pp. 20 - 26. 